\title{
Allozyme variability in the Italian wolf (Canis lupus) population
}

\author{
E. RANDI*, V. LUCCHINI* \& F. FRANCISCI† \\ */stituto Nazionale per la Fauna Selvatica, via Cà Fornacetta 9, 40064 Ozzano Emilia (Bo); and † Via Montegrande 5, \\ 42030 Ramiseto (Re), Italy
}

\begin{abstract}
Multilocus protein electrophoresis was used to estimate genetic variability in a sample of 38 Italian wolves (Canis lupus). Percentage of polymorphic loci was $p=10.0$ per cent (four polymorphic loci out of 40 examined), and average observed heterozygosity was $\overline{\mathrm{Ho}}=0.028$. Genotypes were in Hardy-Weinberg equilibrium. Electrophoretic analysis does not indicate a significant reduction of genetic variability at nuclear gene loci following at least one century of isolation from other European populations and demographic fluctuations suggested by recent range contraction and expansion. These findings are compared with published allozyme and mitochondrial DNA data for dogs, Canadian wolves, and introgressed wolf $\times$ coyote populations from Minnesota and Isle Royale (U.S.A.).
\end{abstract}

Keywords: allozyme electrophoresis, Canis lupus, conservation genetics, dog, genetic variability, wolf.

\section{Introduction}

Systematic persecution of wolves in western Europe during the last two centuries has reduced their previously continuous distribution to patchy remnants. The Iberian and Italian populations have survived prolonged isolation, unlike other populations in Europe (Council of Europe, 1990). Cagnolaro and co-workers (1974) date the confinement of wolves south of the Po River to the turn of the last century.

Zimen \& Boitani (1975) suggested that the Italian wolves declined until the end of the 1960 s, when they were estimated to survive in 10 isolated populations scattered along the Apennines. The authors, extrapolating counts from three such 'islands' to the remainder, concluded that about 100 wolves survived in Italy in 1973. Two years later the species was listed as fully protected nationwide. According to Boitani (1984), diminished persecution eventually allowed wolves to disperse into larger ranges and increase population size. Interbreeding with free-ranging dogs, abundant in the central and southern Apennines, was indicated as both a threat to the integrity of the wolf gene-pool, and as an aid to the recovery of the population, when effective in counteracting inbreeding depression and genetic drift (Boitani, 1984). A track count conducted in

*Correspondence: Ettore Randi, Istituto Nazionale per la Fauna Selvatica, via Cà Fornacetta 9, 40064 Ozzano Emilia (Bo), Italy. winter 1983 in the same three 'wolf-islands' surveyed in 1973 and extrapolated to the known range, based on specimens found dead, suggested a total of 220 wolves south of latitude $43^{\circ} 20^{\prime}$ (Fig. 1), partitioned into two populations along latitude $41^{\circ}$ (Boitani, 1984).

In contrast, Cagnolaro et al. (1974) document a lower degree of population decline and fragmentation. According to their findings, territorial and dispersing wolves in 1972 ranged almost uninterrupted along the Apennines between latitude $44^{\circ}$ and $39^{\circ}$ (Fig. 1). That population was large enough to support an average of 63 legal-kills per year during the decade 1960-70, a figure contrasting with the low population size estimated by Zimen \& Boitani (1975). Francisci \& Guberti (1993) analysed specimens found dead and suggested that the Italian wolf population remained quite stable. Its slow recovery over the last 20 years added approximately $1^{\circ}$ latitude to both the northern and southern extremes of the range assessed in 1972 by Cagnolaro et al. (1974). The present population is estimated at 300 (Boitani et al., 1989), or 400 (Boscagli, 1991).

The genetic structure of the Italian wolf population, although relevant for the conservation of the species (Boitani, 1992), has not been investigated previously. In this paper we study genetic variability at structural genes in a sample of wolves from central-northern Italy, using multilocus protein electrophoresis. We dis- 

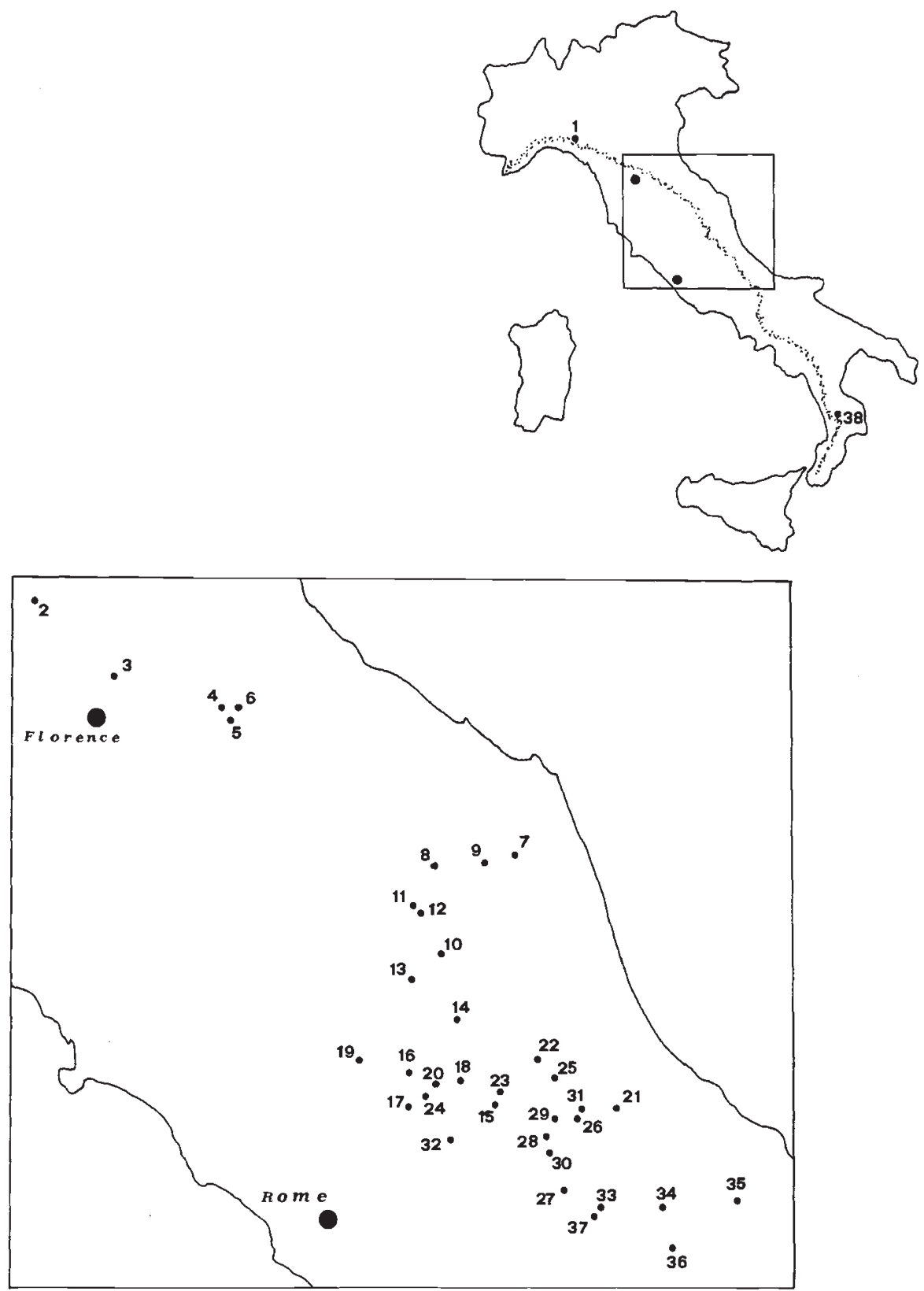

Fig. 1 Distribution of the wolves sampled. Individual genotypes are listed in Table 2. The inset shows the area from which most of the samples were collected. Dusted line represents divide of Apennine range.

cuss our results in the context of available demographic information for wolves in Italy.

The possible effects of over one century of isolation from other European populations, and those possible over the last decades with either an undivided, rather persistent population, or one that fragmented to nearannihilation and rapidly recovered, are also taken into account. Estimating rates of erosion of genetic variability and increase in homozygosity, as well as detecting introgression of dog genes into the wolf population, add information valuable for effective wolf conservation in Italy.

\section{Materials and methods}

Tissue samples (liver and heart) were obtained from 38 wolves, most of them collected in central-northern peninsular Italy (Fig. 1) from 1986 to 1991. These specimens were illegally shot ( 45 per cent), snared ( 15 per cent), or poisoned ( 25 per cent), while 15 per cent were killed by vehicles. Samples were stored at $-80^{\circ} \mathrm{C}$ until processing. About $1 \mathrm{~g}$ of each tissue was separately homogenized in $1 \mathrm{ml}$ of $0.01 \mathrm{~m}$ Tris $/ \mathrm{HCl}, p \mathrm{H} 7.5$, $0.001 \mathrm{M} \mathrm{Na}_{2}$ EDTA, $0.001 \mathrm{M} \beta$-mercaptoethanol buffer, and centrifuged for $15 \mathrm{~min}$ at 13,000 r.p.m., at 
$4^{\circ} \mathrm{C}$. Clear supernatants were diluted in 1 volume of a 40 per cent glycerol solution, aliquoted in microtiter plates, and frozen at $-80^{\circ} \mathrm{C}$ until use. Vertical (VPAGE) and horizontal (HPAGE) polyacrylamide gel electrophoresis ( 7.5 per cent monomers concentration in the resolving gels) were used to study allozyme variation at 40 loci (Table 1). Several enzymes were resolved in more than one buffer system. Staining recipes were adapted from Harris \& Hopkinson (1976).

Electromorphs were presumed to have a simple genetic basis, and were considered as alleles. Alleles were coded according to their mobility from the origin, with the most anodal allele designated as ' $a$ '. Loci were coded with numbers, -1 being the most anodal, usually corresponding to the cytoplasmic isozymes, and -2 corresponding to the mitochondrial isozymes.

The program BIOSYS-1 (Swofford \& Selander, 1989) was used to compute allele frequencies, effective allele number $(\mathrm{A})$, percentage of polymorphic loci $(\mathrm{P} ; 1$ per cent criterion), and heterozygosity $(\mathrm{H})$ values.
Agreement with Hardy-Weinberg expectations was tested by Chi-square (Sokal \& Rohlf, 1981) and exact probability (Weir, 1990) tests.

\section{Results}

Four loci (GPI, DIA-1, GOT-1, MPI) out of 40 resolved, were polymorphic in the Italian wolf samples. Individual genotypes and allele frequencies are shown in Table 2 and Table 3, respectively. Heterozygote patterns corresponded to expectations based on the known quaternary structure of these enzymes in vertebrate species (Harris \& Hopkinson, 1976). GPI showed three alleles, while the other loci showed two. The average effective allele number was $\overline{\mathrm{A}}=1.1$ (over all loci), and 2.3 (polymorphic loci only). Percentage of polymorphism was $\mathrm{P}=10.0$ per cent; average observed and expected heterozygosities were $\overline{\mathrm{Ho}}=0.028$ and $\overline{\mathrm{He}}=0.029$, respectively (Table 4$)$. The greatest con-

Table 1 List of the studied protein loci and electrophoretic conditions

\begin{tabular}{|c|c|c|}
\hline Buffer system & Reference & Locus (E.C.N.) \\
\hline $\begin{array}{l}\text { Discontinuous Tris/glycine } \\
\quad(p \mathrm{H} 8.3 \text { VPAGE })\end{array}$ & Davis, 1964 & $\begin{array}{l}A C P(3.1 .3 .2) \\
A M Y(3.2 .1 .1) \\
M D H-1(1.1 .1 .37) \\
M E-1(1.1 .1 .40) \\
F U M(4.2 .1 .2) \\
G L U D(1.4 .1 .3) \\
G D A(3.5 .4 .3) \\
\text { Albumin }(A L B) \\
\text { Proteins }(H P T-1,-2,-3) \\
\text { SOD-1,-2(1.15.1.1) } \\
C K(2.7 .3 .2) \\
L D H-1,-2(1.1 .1 .27)\end{array}$ \\
\hline Tris/barbital ( $p \mathrm{H} 7.0$ VPAGE) & Williams \& Reisfeld, 1964 & $\begin{array}{l}\alpha G P D H(1.1 .1 .8) \\
M E-2(1.1 .1 .40) \\
I D H-1,-2(1.1 .1 .42) \\
E S T-1,-2,-3,-4,-5(3.1 .1 .1) \\
L A-P E P-A(3.4 .11) \\
L G G-P E P-B(3.4 .11)\end{array}$ \\
\hline Phosphate ( $p$ H 7.0 HPAGE) & Harris \& Hopkinson, 1976 & $6 P G D(1.1 .1 .44)$ \\
\hline Tris/borate/EDTA ( $p \mathrm{H} 8.6 \mathrm{HPAGE})$ & Harris \& Hopkinson, 1976 & $\begin{array}{l}\text { NADH DIA-I }(1.6 .2 .2) \\
\text { NADPH DIA-2 }(1.6)\end{array}$ \\
\hline Tris/phosphate ( $p \mathrm{H} 8.3 \mathrm{HPAGE})$ & Harris \& Hopkinson, 1976 & $M P I(5.3 .1 .8)$ \\
\hline $\mathrm{LiOH} /$ boric acid $(p \mathrm{H}$ 7.2 HPAGE) & Harris \& Hopkinson, 1976 & $N P(2.4 .2 .1)$ \\
\hline
\end{tabular}


Table 2 Individual genotypes at polymorphic loci for 38 Italian wolves (locations shown in Fig. 1)

\begin{tabular}{|c|c|c|c|c|}
\hline \multirow{2}{*}{$\begin{array}{l}\text { Wolf } \\
\text { number }\end{array}$} & \multicolumn{4}{|c|}{ Enzyme locus } \\
\hline & $G P I$ & $G O T-1$ & $M P I$ & $D I A-1$ \\
\hline 1 & $\mathrm{bb}$ & aa & aa & bb \\
\hline 2 & $\mathrm{bc}$ & $a b$ & $a b$ & $a b$ \\
\hline 3 & bb & аa & aа & aa \\
\hline 4 & $\mathrm{bb}$ & aa & aa & $\mathrm{bb}$ \\
\hline 5 & $\mathrm{bb}$ & aa & $a b$ & bb \\
\hline 6 & bb & aa & $a b$ & $a b$ \\
\hline 7 & bb & aa & aa & $a b$ \\
\hline 8 & $\mathrm{bb}$ & aа & aa & $\mathrm{bb}$ \\
\hline 9 & $\mathrm{bc}$ & aа & аa & bb \\
\hline 10 & $\mathrm{bb}$ & aa & aa & aa \\
\hline 11 & bb & aa & $a b$ & $\mathrm{bb}$ \\
\hline 12 & $\mathrm{bb}$ & aa & aа & $\mathrm{bb}$ \\
\hline 13 & $\mathrm{bb}$ & $a b$ & aa & bb \\
\hline 14 & bb & aa & $a b$ & $\mathrm{bb}$ \\
\hline 15 & $\mathrm{bb}$ & aa & aa & $\mathrm{bb}$ \\
\hline 16 & bb & aa & aa & aa \\
\hline 17 & bc & aa & aa & $a b$ \\
\hline 18 & $\mathrm{bb}$ & aa & $\mathrm{bb}$ & $a b$ \\
\hline 19 & $\mathrm{bb}$ & aa & $a b$ & $\mathrm{bb}$ \\
\hline 20 & bb & aa & $a b$ & aa \\
\hline 21 & $\mathrm{bb}$ & $a b$ & $\mathrm{ab}$ & $\mathrm{ab}$ \\
\hline 22 & $\mathrm{bc}$ & aa & aa & bb \\
\hline 23 & $\mathrm{bb}$ & aa & $a b$ & $a b$ \\
\hline 24 & bb & aa & aa & bb \\
\hline 25 & $\mathrm{bb}$ & aa & $a b$ & aa \\
\hline 26 & $\mathrm{bb}$ & aа & aа & $a b$ \\
\hline 27 & $\mathrm{bb}$ & aa & $a b$ & aa \\
\hline 28 & $a b$ & aа & $a b$ & $\mathrm{bb}$ \\
\hline 29 & $\mathrm{bb}$ & aa & $\mathrm{bb}$ & $a b$ \\
\hline 30 & bc & aa & $a b$ & $\mathrm{bb}$ \\
\hline 31 & bc & aa & aa & $\mathrm{bb}$ \\
\hline 32 & bb & aa & $a b$ & $\mathrm{bb}$ \\
\hline 33 & $\mathrm{bb}$ & aa & $a b$ & $\mathrm{bb}$ \\
\hline 34 & $\mathrm{bb}$ & aa & $a b$ & $\mathrm{bb}$ \\
\hline 35 & bc & aa & $a b$ & $a b$ \\
\hline 36 & $\mathrm{bb}$ & $a b$ & $a b$ & $\mathrm{bb}$ \\
\hline 37 & $\mathrm{bb}$ & aa & $a b$ & $a b$ \\
\hline 38 & bb & aa & $\mathrm{bb}$ & $a b$ \\
\hline
\end{tabular}

Table 3 Allele frequencies at polymorphic loci in a sample of 38 wolves from central-northern Italy

\begin{tabular}{rcccc}
\hline Loci & GPI & GOT-1 & MPI & DIA-1 \\
\hline Alleles a & 0.013 & 0.947 & 0.671 & 0.316 \\
b & 0.895 & 0.053 & 0.329 & 0.684 \\
c & 0.092 & 0.000 & 0.000 & 0.000 \\
\hline
\end{tabular}

tributions to average heterozygosity were from $M P I$ and DIA-1 (average heterozygosity $\overline{\mathrm{Ho}}=0.45$ ). Commonest alleles for GPI and GOT-1 were at a frequency higher than 0.89 , and their heterozygosities were lower than 0.20 . All polymorphic loci were in Hardy-Weinberg equilibrium, and heterozygote genotypes were scattered over all the sampled area (Fig. 1 and Table 2).

Allozyme variability in the Italian wolves was compared (Table 4) with recently published data on wolf populations from Canada (Kennedy et al., 1991), Minnesota and Isle Royale, U.S.A., (Wayne et al., 1991). Minnesota wolves belong to a wolf $\times$ coyote (Canis latrans) hybrid population, as determined by mtDNA analysis (Lehman et al., 1991). All the Isle Royale wolves possess the same mtDNA haplotype, which is of coyote origin (Lehman et al., 1991). A low percentage of polymorphic loci $(\mathrm{P}=8.0 ; 1$ per cent criterion) was observed in the small population (only 14 survivors in 1990) on Isle Royale. This island population showed less than 40 per cent polymorphic loci compared with the nearby mainland Minnesota hybrid population $\langle\mathrm{P}=20.0$ per cent). The observed low genetic diversity of the Isle Royale wolves can result (at least in part) from the very low sample $(n=7)$. Wolves sampled in Canada showed $\mathrm{P}=17.9$ per cent ( 1 per cent criterion), slightly lower than the Minnesota hybrid population. The Italian wolves were intermediate between the Isle Royale and the mainland North America populations (Table 4). Heterozygosity values were similar in the Italian, Canada, and Isle Royale populations ( $\overline{\mathrm{Ho}}$ ranging from 0.028 to 0.040 ), and were $40-50$ per cent $(P<0.001, t$-test $)$ lower than in the Minnesota hybrid population (Table 4).

\section{Discussion}

Generalized hybridization with free-ranging dogs was postulated (Boitani, 1984) as one of the major factors allowing the supposedly quick recovery of wolves in Italy during the late 1970 s-early 1980 s, and is still regarded as the main threat to the species' survival at present (Boitani, 1992).

The few studies comparing allozyme variability among canids could not detect any single-locus fixed difference between dog and wolf (Simonsen, 1976; Fisher et al., 1976; Ferrel et al., 1980; Braend \& Roed, 1987). Genetic distances generated through multilocus protein electrophoresis were low, indicating close phylogenetic relationships among coyote, jackal (Canis aureus), wolf, and $\operatorname{dog}$ (Seal, 1975; Wayne \& O'Brien, 1987). Evolutionary divergence among these canids was accordingly estimated to be fairly recent $(2$ million years; Wayne \& O’Brien, 1987). 
Table 4 Percent polymorphic loci $(\mathbf{P} \%, 0.01$ criterion), observed heterozygosity $(\mathrm{Ho})$, and expected heterozygosity $(\mathrm{He})$ in Italian and North American wolf populations

\begin{tabular}{|c|c|c|c|c|}
\hline \multirow[b]{2}{*}{ Population: } & \multicolumn{2}{|l|}{ Wolf } & \multicolumn{2}{|c|}{ Introgressed wolf $\times$ coyote $(a)$} \\
\hline & $\begin{array}{l}\text { Italy }(\mathbf{b}) \\
(n=32)\end{array}$ & $\begin{array}{l}\text { Canada }(\mathrm{c}) \\
(188)\end{array}$ & $\begin{array}{l}\text { Isle Royale } \\
\text { (7) }\end{array}$ & $\begin{array}{l}\text { Minnesota } \\
(33)\end{array}$ \\
\hline$p \%(0.01)$ & 10.0 & 17.9 & 8.0 & 20.0 \\
\hline Ho & 0.028 & 0.030 & 0.040 & 0.061 \\
\hline $\mathrm{He}$ & 0.029 & $\mathrm{NC}(\mathrm{d})$ & 0.039 & 0.087 \\
\hline
\end{tabular}

(a) Wayne et al., 1991. (b) Sampling area shown in Fig. 1.(c) Kennedy et al., 1991.

(d) $\mathrm{NC}=$ not computed.

Loci that we have found polymorphic in Italian wolves, were also polymorphic in other wolf populations (Kennedy et al., 1991; Wayne et al., 1991), and in several dog breeds (Meera Khan et al., 1973; Weiden et al., 1974; Fisher et al., 1976; Arnold \& Bouw, 1985). Genetic variability of gene-enzyme systems has been studied in large samples of many and differing dog breeds. According to these studies we may infer average values of $\mathrm{P}$ ranging from 10 to 20 per cent, and $\overline{\mathrm{Ho}}$ ranging from 0.030 to 0.040 in domestic dogs, roughly compare with estimates found in wolf populations (Kennedy et al., 1991; Wayne et al., 1991; this study). Allozyme variability may not detect hybridization of wolves with dogs, unless exhaustive samples of sympatric dogs and wolves are available from areas of possible hybridization. Careful estimation of allele frequencies at many polymorphic loci, or use of species-specific DNA markers is needed to investigate possible gene flow between dog and wolf.

Preliminary restriction fragment length polymorphism (RFLP) analysis showed that mtDNA was monomorphic in 14 Italian wolves collected by the Italian Institute for Wildlife Biology (INFS) during 1986-1989 (Wayne et al., 1992). The single mtDNA Italian wolf haplotype was distinct from other European and North American wolf and dog samples (Wayne et al., 1992). Recent RFLP analysis of an expanded sample ( $n=30)$ confirmed the monomorphism of mtDNA of Italian wolves, and discovered the existence of fixed sequence differences with free-ranging dogs (Randi et al., in preparation). Therefore, mtDNA findings offer no evidence of widespread maternal introgression of dog genes into the present Italian wolf gene pool. If wolf $\times$ dog hybridization is sex biased, mtDNA cannot be used as a marker. Dog $\times$ wolf hybridization is known for wolves of both sexes, although published reports of hybridization in nature refer to she-wolves (Boitani, 1984; Zimen, 1978 , for one case in Italy; Mendelssohn, 1982, for one in Israel). Examples of hybrid populations or evidence for introgression, however, are not known. Interbreeding was not apparent during a 4-year study of sympatric wolves and dogs in Abruzzo. Feral dogs adjacent to, or included in, wolves' territories, survived by minimizing contact with the latter species (Francisci et al., 1992).

Though Italian and Canadian wolves show similar values of heterozygosity and percentage of polymorphic loci (Table 4), the former are monomorphic at $M E-1$ and $P G M-1$, where the latter are polymorphic, with variants at low frequencies (Kennedy et al., 1991). It may be expected that a relatively large and uniformly distributed sample of wolves in Italy would increase the probability of detecting polymorphic loci, although this might be counteracted by both isolation and demographic fluctuations.

Available information support our findings that wolves in northern-central peninsular Italy behave as a single panmictic population in Hardy-Weinberg equilibrium. Heterozygote genotypes were randomly distributed throughout the sampled area (Table 2), while allozyme variability does not indicate inbreeding or population subdivision (Wahlund effect; Hartl \& Clark, 1989). Because we were not able to obtain specimens from the southern Apennines we cannot comment on the degree of local genetic divergence. The habitat continuum which the Apennines still offers to wolves, particularly to dispersers, suggests the species in Italy has probably remained panmictic through its range ( $c f$. Ciucci \& Boitani, 1991). Finer population subdivisions will have to be assessed by sampling different packs and by analysis of fast-evolving DNA sequences (mtDNA and DNA fingerprinting).

Our findings indicate that the bulk of genetic variability in wolves in northern-central Italy has not been lost. Moderate bottlenecks may cause loss of rare and lowfrequency alleles or mtDNA haplotypes (Nei et al., 1975). If mtDNA monomorphism is confirmed on a 
larger sample size, more complex metapopulation dynamics should be taken into account. For example, isolation from continental populations effective since before the last 100 years (Cagnolaro et al., 1974), might have significantly reduced the species' variability in Italy, even in the absence of bottlenecks, when combined with a steady population decrease (Wayne et al., 1991). Repeated local extinction and recolonization (Boitani, 1992) might have greatly reduced the effective population size and sped up the erosion of genetic variability due to random drift (Gilpin, 1991) in the Italian wolf population. Availability of larger samples of Italian and other European populations, may allow a better understanding of the population genetics of wolves in Italy and the extent of geographical differentiation in Europe.

\section{Acknowledgements}

We wish to thank all those who helped collect founddead wolves, particularly Cesare Cavalieri. The Forestry Corps (CFS), a branch of the Ministry of Agriculture and Forests, made an increasing number of illegally killed wolves available to INFS. Francesco Francisci benefited from an Advanced NATO Fellowship (215.237/1989) made available by the National Research Council (CNR) in Rome and the School of Forestry of the University in Munich, Germany. We acknowledge the helpful comments of an anonymous referee, which greatly improved the paper.

\section{References}

ARNOLD, I. C. J. AND Bouw, J. 1985. Biochemical variants in dogs. Anim. Blood Grps. Biochem. Genet., 16, Suppl. 1 54-55 (abst).

ARNOLD, I. C. J. AND Bouw, J. 1989. A new allele of glucose phosphate isomerase in dogs. Anim. Genet., 20, 217-220.

BOITANI, L. 1984. Genetic considerations on wolf conservation in Italy. Boll. Zool., 51, 367-373.

BOITANI, L. 1992. Wolf research and conservation in Italy. Biol. Cons., 61, 125-132.

BOITANI, L., CIUCCI, P., CORSI, F. AND FABBRI, M. L. 1989. Assessing actual and potential wolf range in Italy with the aid of a GIS. In: 5th Intl. Theriol. Conf. Abstracts, Rome.

BosCAGLI, G. 1991. Evoluzione del nucleo di lupi appenninici (Canis lupus italicus) in cattività nel Parco Nazionale d'Abruzzo e situazione della popolazione italiana di lupo. Situazione della popolazione di orso (Ursus arctos marsicanus) in Appennino centrale. In: Randi, E. and Spagnesi, M. (eds.) Genetics and Wildlife Conservation. Suppl. Ric. Biol. Selvaggina. XVIII, pp. 219-225.

BRAEND, M. AND ROED, K. H. 1987. Polymorphism of transferrin and esterase in Alaskan wolves: evidence of close molecular homology with the dog. Anim. Genet., 18, 143-148.
CAGNOlaro, L., RosSo, D., SPAGNESI, M. AND VENTURI, B. 1974. Inchiesta sulla distribuzione del lupo (Canis lupus) in Italia e nei Cantoni Ticino e Grigioni (Svizzera). Ric. Biol. Selvaggina, 59, 1-75.

CIUCCI, P. AND BOITANI, L. 1991. Viability assessment of the Italian wolf and guidelines for the management of the wild and a captive population. Ric. Biol. Selvaggina, 89, 1-58.

COUNCIL OF EUROPE, 1990. Status and conservation needs of the wolf in the Council of Europe member states (M. Delibes, ed.). Nature and Environment Series, Strasbourg, 47, 1-46.

DAVIS, B. J. 1964. Disc electrophoresis. II. Method and application to human serum proteins. Ann. N. Y. Acad. Sci., 121, 404-427.

FERREL, R. A., MORIZOT, D. C., HORN, J. AND CARLEY, C. J. 1980. Biochemical markers in a species endangered by introgression: the red wolf. Biochem. Genet., 18, 39-49.

FISHER, R. A., PUTT, w. AND HACKEL, E. 1976. An investigation of the products of 53 gene loci in three species of wild Canidae: Canis lupus, Canis latrans and Canis familiaris. Biochem. Genet., 14, 963-974.

FRANCISCI, F., CIUCCI, P., ANDREOLI, G. AND BOITANI, L. 1992. Storia naturale di un gruppo di cani inselvatichiti nell'areale di presenza del lupo in Marsica. Unpublished final report to the Italian Institute for Wildlife Biology (in Italian).

FRANCISCI, F. AND GUBERTI, V. 1993. Recent trends of wolves in Italy as apparent from kill figures and specimens. Paper accepted for proceedings of symposium Wolves in Europe: current status and prospects. Oberammergau (FRG), 2-5 April 1992, Wildbiologische Gesellschaft Muenchen.

GILPIN, M. 1991. Intellectual challenges of biodiversity conservation. In: Randi, E. and Spagnesi, M. (eds.) Genetics and Wildlife Conservation. Suppl. Ric. Biol. Selvaggina. XVIII, pp. 19-27.

HARRIS, H. AND HOPKINSON, D. A. 1976. Handbook of Enzyme Electrophoresis in Human Genetics. North Holland Publ. Co., Amsterdam.

haRTL, D. L. AND Clark, A. G. 1989. Principles of Population Genetics. Sinauer, Sunderland.

JOLLEY, w. B. AND ALLEN, H. w. 1965. Formation of complexes between basic proteins of leucocytes and plasma globulins. Nature, 208, 390-391.

KENNEDY, P. K., KENNEDY, M. L., CLARKSON, P. L. AND LEIPINS, I. S. 1991. Genetic variability in natural populations of the gray wolf, Canis lupus. Can. J. Zool., 69, 1183-1188.

LEHMAN, N., EISENHAWER, A., HANSEN, K., MECH, D. L., PETERSON, R. O., GOGAN, P. J. P. AND WAYNE, R. K. 1991. Introgression of coyote mitochondrial DNA into sympatric North American gray wolf populations. Evolution, 45, 104-119.

MEERA KHAN., LOS, W. R. T., DOES, J. A. AND EPSTEIN, R. B. 1973. Isoenzyme markers in dog blood cells. Transplantation, 15, 624-628.

MENDELSSOHN, M. 1982. Wolves in Israel. In: Harrington \& Paquet (eds) Wolves of the World. Noyes Publications, Park Ridge, NY, pp. 173-195.

NEI, M., MARUYAMA, T. AND CHAKRABORTY, R. 1975. The bottleneck effect and genetic variability in populations. Evolution, 29, 1-10. 
SEAL, U. S. 1975. Molecular approaches to taxonomic problems in the Canidae. In: Fox, M. W. (ed.) The Wild Canids: their systematics, behavioral ecology and evolution. Van Nostrand Reinhold Co., New York, pp. 27-39.

SIMONSEN, v. 1976. Electrophoretic studies on the blood proteins of domestic dogs and other Canidae. Hereditas, 82, $7-18$.

SOKAL, R. R. AND ROHLF, R. J. 1981. Biometry, W. H. Freeman, San Francisco.

SWOFFORD, D. L. AND SELANDER, R. K. 1989. BIOSYS-1. A computer program for the analysis of allelic variation in population genetics and biochemical systematics. Release. 1.7. Illinois.

WAYNE, R. K. AND O'BRIEN, S. J. 1987. Allozyme divergence within the Canidae. Syst. Zool., 36, 339-355.

WAYNE, R. K., GILBERT, D. A., EISENHAWER, A., LEHMAN, N., HANSEN, K., GIRMAN, D., PETERSON, R. O., MECH, L. D., GOGAN, P. J. P., SEAL, U. S. AND KRUMENACKER, R. J. 1991. Conservation genetics of the endangered Isle Royale gray wolf. Cons. Biol., 5, 41-51.

WAYNE, R. K., LEHMAN, N., ALLARD, M. W. AND HONEYCUTT, R. L. 1992. Mitochondrial DNA variability of the gray wolf: genetic consequences of population decline and habitat fragmentation on genetic variability. Cons. Biol., in press.

WEIDEN, P., STORB, R., KOLB, H. J., GRAHAM, T., ANDERSON, J. AND GIBLETT, E. 1974. Genetic variation of red blood cell enzymes in the dog. Transplantation, 17, 115-120.

WeIR, B. S. 1990. Genetic Data Analysis, Sinauer Associates, Sunderland, Massachusetts.

WILliAMS, D. E. AND REISFELD, R. A. 1964. Disc electrophoresis in polyacrylamide gels: extension to new conditions of $\mathrm{pH}$ and buffers. Ann. N. Y. Acad. Sci., 121, 373-381.

zIMEN, E. 1978. Der Wolf, Mythos und Verhalten, Meyster Verlag, Wien.

ZIMEN, E. AND BOITANI, L. 1975. Number and distribution of wolves in Italy. Z. Saugetierk., 40, 102-112. 